\title{
Methylation Status and Expression of BRCA2 in Epithelial Ovarian Cancers in Indonesia
}

\author{
Heru Pradjatmo
}

\begin{abstract}
Ovarian cancer is the main cause of mortality in gynecological malignancy and extensive studies have been conducted to study the underlying molecular mechanisms. The BRCA2 gene is known to be an important tumor suppressor in ovarian cancer, thereby BRCA2 alterations may lead to cancer progression. However, the BRCA2 gene is rarely mutated, and loss of function is suspected to be mediated by epigenetic regulation. In this study we investigated the methylation status and gene expression of BRCA2 in ovarian cancer patients. Ovarian cancer pateints $(n=69)$ were recruited and monitored for 54 months in this prospective cohort study. Clinical specimens were used to study the in situ expression of aberrant BRCA2 proteins and the methylation status of BRCA2. These parameters were then compared with clinical parameters and overall survival rate. We found that BRCA2 methylation was found in the majority of cases $(\mathbf{9 8 . 7 \%})$. However, the methylation status was not associated with protein level expression of BRCA2 (49.3\%). Therefore in addition to DNA methylation, other epigenetic mechanisms may regulate BRCA2 expresison. Our findings may become evidence of BRCA2 inactivation mechanism through DNA methylation in the Indonesian population. More importantly, from multivariate analysis, BRCA2 expression was correlated with better overall survival (HR $0.32 ; p=0.05)$. High percentage of BRCA2 methylation and correlation of BRCA2 expression with overall survival in epithelial ovarian cancer cases may lead to development of treatment modalities specifically to target methylation of BRCA genes.
\end{abstract}

Keywords: BRCA2 - epigenetic - methylation - epithelial ovarian cancer - survival

Asian Pac J Cancer Prev, 16 (18), 8599-8604

\section{Introduction}

Cancer progression is typically controlled by progressive genetic abnormalities, including mutations in tumor suppressor genes, oncogenes and chromosomal abnormalities including gene amplification, gene deletion, point mutation, chromosomal rearrangement and chromosomal aneuploidy. In addition, cancer is also apparently controlled by "epigenetic changes" that regulate the genetic alterations and molecular regulations of tumor biology (Herman \& Baylin, 2003; Jones, 1996). These epigenetic changes occur at a higher frequency than genetic changes and can be reversibly regulated with pharmacological means. Therefore, research on epigenetic regulations of cancer biology is uprising due to the possibility of translation into clinical setting for diagnosis and therapeutic development.

BRCA1 and BRCA2 are tumor suppressor genes that encode proteins for DNA repair mechanism. Their mutation or loss of function are associated with the development of ovarian cancer and breast cancer (Gudmundsdottir \& Ashworth, 2006; Venkitaraman, 2002). Therefore, BRCA1 and BRCA2 genes are mentioned as "breast-ovarian cancer susceptibility genes" that act as genetic risk factors for ovarian and breast cancer. Spontaneous mutation of the BRCA1 and BRCA2 genes is rare, and loss function of BRCA1 and BRCA2 genes is suspected due to epigenetic changes that occur more frequently, while other means of gene inactivation yet studied intensively (Thrall et al, 2006). The prevalence of ovarian cancer varies extensively among different geographic regions and ethnic groups (Holschneider \& Berek, 2000; Thrall et al, 2006), which may reflect alterations in methylation status of tumor suppressor genes. Therefore, we studied the methylation status of BRCA2 in epithelial ovarian cancer.

DNA methylation is a covalent chemical modification that results in the addition of a methyl $(\mathrm{CH} 3)$ group at the carbon-5 position of the cytosine ring. The human genome is not methylated uniformly and contains regions of unmethylated segments interspersed by methylated regions. DNA methylation at $\mathrm{CpG}$ sites of the promoter region can alter gene expression, which has recently been considered as important regulator for tumor development and progression (Olek et al, 1996; Korstanje et al, 2004; Yanagawa et al, 2004). The inactivation of tumorsuppressor genes due to $\mathrm{CpG}$ island methylation has 
been implicated as one of the major pathways during cancer progression (An et al, 2010). Methylation is a key silencing mechanism of breast and ovarian cancer susceptibility for BRCA1, however less known about BRCA2 (Bosviel et al, 2011). The BRCA2 protein is important to preserve genomic stability by ensuring high fidelity repair of double-strand DNA breaks (McCabe et al, 2006). Previous studies reported BRCA1 methylation in ovarian cancer was 5\% (Catteau et al, 1999), $15 \%$ (Baldwin et al, 2000), 19\% (Hedenfalk et al, 2001), 10\% (Rathi et al, 2002), 31\% (Meetei et al, 2004), even in our previous study in the Indonesian population found BRCA1 methylation as high as $89.9 \%$ (Pradjatmo et al, 2014). These results support that the abnormal promoter methylation in BRCA1 may have an important role in tumorigenesis in some types of ovarian cancer. However, methylation of BRCA2 in ovarian cancer development is still not clearly understood. Dhillon et al. reported their studied found methylation of BRCA2 was 1/25 (4\%) in granulosa cell tumors (Dhillon et al, 2004), in Iran found BRCA2 methylation of epithelial ovarian cancer were 7/60 (11.7\%) (Darehdori et al, 2012; Shabanizadeh et al, 2013). Therefore, it is necessary to study the BRCA2 methylation status in our population.

\section{Materials and Methods}

\section{Clinical samples recruitment}

The protocols to study BRCA2 methylation status was following previously reported protocol for BRCA1 (Pradjatmo et al, 2014). The study design was a prospective cohort that was conducted at Sardjito Hospital, Yogyakarta, Indonesia. All of the patients $(n=69)$ gave signed, informed consent for their tissues to be used for scientific research. Recommendations of the Declaration of Helsinki for biomedical research were also followed

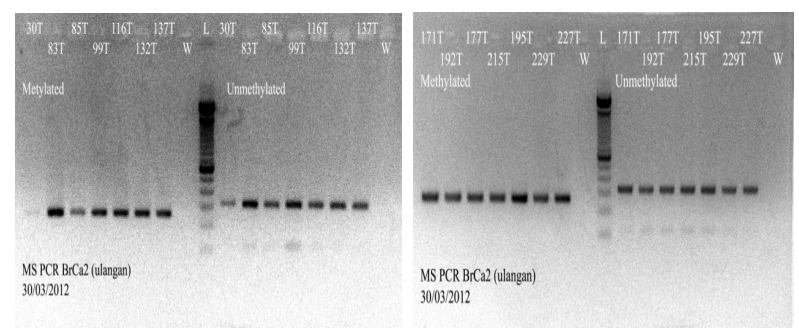

Figure 1. The Result Electrophoresis of BRCA2 Methylation of Some Sample of the Epithelial Ovarian Cancer
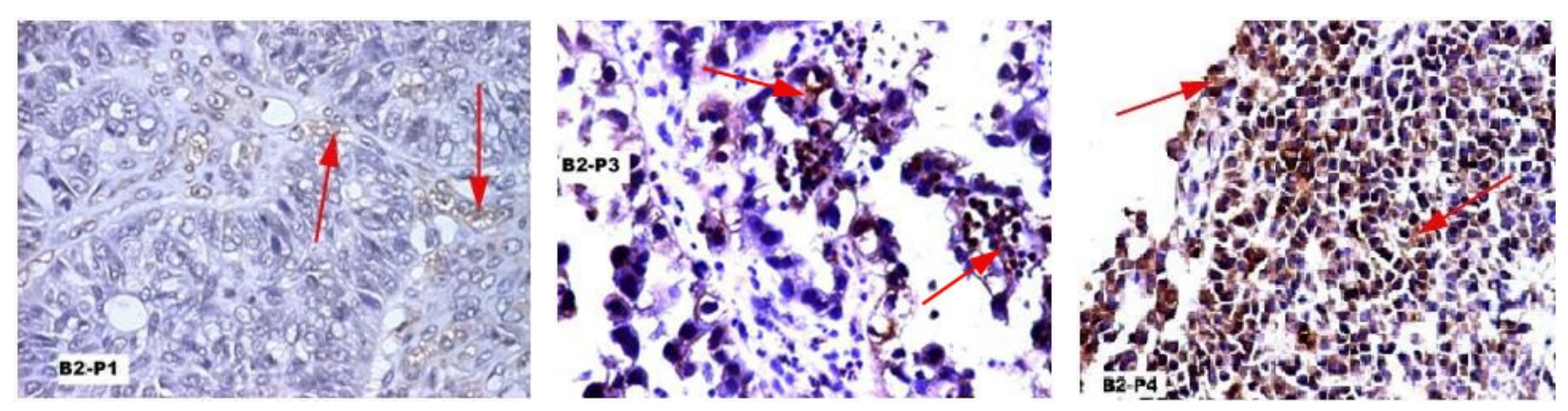

Figure 2. IHC Examination of BRCA2 (brown staining): (B2-P1) Show Positive 1 Staining, (B2-P3 Show Positive 3 Staining(B2-P4) Show Positive 4 Staining

to get the approval by Joint Institutional Review Board (JIRB) Faculty of Medicine, the Universitas Gadjah Mada (No:KE/FK/730/FC). Tissues collected from ovarian cancer patients were stored at $-70 \mathrm{C}$, then the tissues were used to study the methylation status of BRCA2 by methylation specific PCR (MSP), while some of the tissues were examined at pathology anatomy department to determine the type of histopathology, the degree of differentiation and the in situ protein expression of BRCA2.

\section{BRCA2 methylation status examination}

Methylation status of BRCA2 was clarified following standard protocol of DNA Mini Kit (Qiagen, Germany). The conversion procedure of DNA bisulphite was following protocol of MethylEasy Xceed Rapid DNA Bisulphite modification Kit. For PCR reaction, $1 \mu$ INA which was previously converted with sodium bisulphide, was added with $18 \mu \mathrm{l}$ PCR mix that contains $1 \mathrm{x}$ PCR buffer, optimum concentration $\mathrm{Mg} 2+$ for each primer, $0.4 \mu \mathrm{l}$ primer and $0.1 \mu \mathrm{l} \mathrm{Taq}$ polymerase. The primer used for BRCA2 were; BRCA2_MF :5'-GAC GGT TGG GAT GTT TGA TAA GG-3', BRCA2_MR :5' AAT CTA TCC CCT CAC GCT CC-3', BRCA2_UF :5'-AGG GTG GTT TGG GAT TTT TAA GG-3', BRCA2_UR ;5' -TCA CAC TTC TCC CAA CAA CAA CC-3' (Dhillon et al, 2004).

\section{Immunohistochemistry (IHC) for BRCA2 expression and scoring}

Paraffin block section 3-5 $\mu$ m thick of ovarian tumor tissue on glass slide was examined for IHC. Monoclonal antibody (Biocare Medical, LLC, 4040, Pike Lane Concord, CA 94520, LA, USA) that specifically reacts with $\mathrm{N}$-terminal portion of the BRCA2 protein was used in this study. The BRCA2-positive breast cancer tissues were used as positive control, while negative control was the same tissues without BRCA2 antibody for staining. The percentage of staining was determined blindly by an independent pathologist. The ascribed score was based on the number of cells with nuclear staining. The score was classified as: slides was score as "zero" if there was no staining, "one" if there was scattered staining $(<10 \%)$. "two" if 10-50\% of the cells were stained, "three" if 50$90 \%$ of cells were stained and "four" if nearly all cells (>90\%) were stained (Figure 2). Tumor were categorized as having aberrant BRCA2 expression for very low to no staining $(<10 \%)$; zero or one score) and positive BRCA2 expression for $>10 \%$ BRCA2 staining (two-four score) 
(Thrall et al, 2006; Lesnock et al, 2013).

\section{Results and Discussion}

BRCA2 methylation was profoundly found in epithelial ovarian cancer

The survival of all subjects $(n=69)$ was followed up. The longest follow-up was 54 months and the shortest was 12 months. Survival months were then compared based on the BRCA2 methylation status. Table 1 showed the methylation of BRCA2 genes in EOC tissue was $68 / 69$ cases $(98.6 \%)$, while tissue without methylation was $1 / 69$ cases $(1.4 \%)$. IHC staining of BRCA2 positive was $34 / 69$ cases $(49.3 \%)$ and aberrant BRCA2 was found in $35 / 69(50.7 \%)$. However, the methylation status and expression of BRCA2 were not statistically associated. There was no agreement between methylation status and protein expression of BRCA2 with Kappa statistic < 0.01 (the agreement less than $1 \%$ ). Some ovarian tumor tissues $(98.6 \%)$ with methylated BRCA2 the tumor tissues still have unmethylated cells either. It can be seen in the electrophoresis result (Figure 1) that although most cancer tissues with methylated BRCA2, the tissues still have band of umethylated BRCA2. It was because not all the cells in the tumor were uniformly methylated or unmethylated. Shabanizadeh et al. in Iran reported that methylation of the BRCA2 promoter of epithelial ovarian cancer was found $11.7 \%$ or 7 of the 60 patients (Darehdori et al, 2012; Shabanizadeh et al, 2013). Of these 60 sporadic epithelial ovarian cancers, $14(23.3 \%)$ had loss, $18(30 \%)$ cases had reduced, and $28(46.6 \%)$ cases had normal BRCA2 protein expression. Of the 14 cases that had a loss of protein expression, 7 cases were methylated in the promoter region. Contrarily, our study found very high percentage of BRCA2 methylation, in $98.6 \%$ of subjects, while 35 patients $(50.7 \%)$ had lost expression BRCA2 protein and 34 patients $(49.3 \%)$ had expressed BRCA2 protein.

The protein expression of BRCA2, as other genes,

Table 1. Kappa Statistic of the Methylation Status of BRCA2 Gene and Expression of BRCA2 Protein

\begin{tabular}{lcrrrrr}
\hline Methylation status BRCA2 & \multicolumn{2}{c}{ I H C BRCA2 $(\mathrm{n}(\%))$} & Total & X2 & p & Kappa \\
& Aberrant/- $<10 \%$ & Normal/+>10 $\%$ & & & & \\
\hline Methylated & $34(49.3 \%)$ & $35(49.3 \%)$ & $68(98.6 \%)$ & 0.986 & 0.321 & $<0.01$ \\
Unmethylated & $1(1.4 \%)$ & $0(0 \%)$ & $1(1.4 \%)$ & & & \\
\hline
\end{tabular}

Table 2. Distribution of Clinicopathological Factors of EOC Patients to the Methylation Status of BRCA2 Gene and IHC of BRCA2 Protein

\begin{tabular}{|c|c|c|c|c|c|c|c|c|}
\hline \multirow[t]{2}{*}{ Variable } & \multicolumn{5}{|c|}{ Methylation status } & \multicolumn{2}{|c|}{ IHC BRCA2 protein } & \multirow[b]{2}{*}{$\mathrm{P}$ value } \\
\hline & Methylated (\%) & Unmethylated (\%) & $\mathrm{RR}$ & $\mathrm{P}$ value & Aberrant (\%) & Normal (\%) & $\mathrm{RR}$ & \\
\hline \multicolumn{9}{|l|}{$\overline{\text { Age }}$} \\
\hline$<40$ years & $18(26.1)$ & $0(0.0)$ & & & 8 (11.6) & $10(14.5)$ & & \\
\hline$>=40$ years & $50(72.5)$ & $1(1.4)$ & 1.02 & 0.73 & $27(39.1)$ & $25(34.8)$ & 1.18 & 0.36 \\
\hline \multicolumn{9}{|l|}{ Age of menarche } \\
\hline$<15$ year old & $46(66.7)$ & $1(1.4)$ & & & $26(37.7)$ & $21(30.4)$ & & \\
\hline$>=15$ year old & $22(31.9)$ & $0(0.0)$ & 0.97 & 0.68 & $9(13.0)$ & $13(18.8)$ & 0.75 & 0.19 \\
\hline \multicolumn{9}{|l|}{ Parity } \\
\hline$<2$ & $0(0)$ & $33(47.8)$ & & & $16(23.2)$ & $17(24.6)$ & & \\
\hline$>=2$ & $1(1.4)$ & $35(50.7)$ & 0.52 & 0.52 & $19(27.5)$ & $17(24.6)$ & 1.018 & 0.45 \\
\hline \multicolumn{9}{|l|}{ Menopause } \\
\hline Non menopause & $35(50.7)$ & $0(0.0)$ & & & $16(23.2)$ & $19(27.5)$ & & \\
\hline Menopause & $33(47.8)$ & $1(1.4)$ & 1.03 & 0.49 & $19(27.5)$ & $15(21.7)$ & 1.23 & 0.27 \\
\hline \multicolumn{9}{|l|}{ BMI } \\
\hline$<25 \mathrm{~kg} \cdot \mathrm{m} 2$ & $51(73.9)$ & $1(1.4)$ & & & $27(39.1)$ & $25(36.2)$ & & \\
\hline$>=25 \mathrm{~kg} / \mathrm{m} 2$ & $17(24.6)$ & $0(0.0)$ & 0.98 & 0.75 & $8(11.6)$ & $9(13.0)$ & 0.90 & 0.47 \\
\hline \multicolumn{9}{|l|}{ CA 125 level } \\
\hline$<=70 \mathrm{IU} / \mathrm{ml}$ & $23(33.3)$ & $0(0.0)$ & & & $11(15.9)$ & $12(17.4)$ & & \\
\hline$>70 \mathrm{IU} / \mathrm{ml}$ & $45(65.2)$ & $1(1.4)$ & 1.02 & 0.66 & $24(34.8)$ & $22(31.9)$ & 1.09 & 0.46 \\
\hline \multicolumn{9}{|l|}{ Clinical stage } \\
\hline Early stage & $23(33.3)$ & $0(0.0)$ & & & $15(21.7)$ & $8(11.6)$ & & \\
\hline Late stage & $45(65.2)$ & $1(1.4)$ & 1.02 & 0.66 & $20(29.0)$ & $26(7.7)$ & 0.61 & 0.07 \\
\hline \multicolumn{9}{|l|}{ Histological type } \\
\hline Serous & $18(26.1)$ & $1(1.4)$ & & & $11(15.9)$ & $8(11.6)$ & & \\
\hline Mucinous & $35(50.2)$ & $0(0.0)$ & & & $17(24.6)$ & $18(26.1)$ & & \\
\hline Others & $15(21.7)$ & $0(0.0)$ & & 0.44 & $7(10.1)$ & $8(11.6)$ & & 0.73 \\
\hline \multicolumn{9}{|c|}{ Grade of differentiation } \\
\hline Well & $35(50.2)$ & $0(0.0)$ & & & $19(27.5)$ & $16(23.2)$ & & \\
\hline Moderate & $15(21.7)$ & $0(0.0)$ & & & $5(7.2)$ & $10(14.5)$ & & \\
\hline Poor & $18(26.1)$ & $1(1.4)$ & & 0.26 & $11(15.9)$ & $8(11.6)$ & & 0.30 \\
\hline \multicolumn{9}{|l|}{ Residual tumor } \\
\hline Optimal surgery & $40(58.0)$ & $0(0.0)$ & & & $22(31.9)$ & $18(26.1)$ & & \\
\hline Not optimal & $28(40.6)$ & $1(1.4)$ & 1.03 & 0.42 & $13(18.8)$ & $16(23.2)$ & 0.81 & 0.27 \\
\hline
\end{tabular}


was regulated by various molecular machineries within the cell. Regulation of expression may be alterred at the level of transcription, translation and post translation. As mentioned by Hilton et al. that the universal inactivation of genes had multiple mechanisms, not only because of mutation and hypermethylation but there were still other mechanisms. These mechanisms include; first, the mutations of gene promoter, so failing to identify the correct $\mathrm{CpG}$ island of gene promoter; second, the loss of the function of gene products required for the transcription of gene, as well as loss of heterozygosity ( $\mathrm{LOH})$ as the third cause (Hilton et al, 2002). Relevant to our study, not all cancer cells showed the negative expression of BRCA2 although the results of the examination of the methylation of BRCA2 gene were positive. Latest reports found that the causes and the early incidence of EOC were governed by a group of genes including microRNA genes, which could be modulated at four levels, namely the level of genomic, transcriptional regulation, post-translation modification and regulatory processes of microRNA ( $\mathrm{Li}$ et al, 2010). It might explain why eventhough tumors had BRCA2 methylations, the expression of the BRCA2 proteins in the tissue was still high.

It is known that BRCA1 and BRCA2 genes function as tumor suppressor genes mainly through repairing doublestranded DNA damage. Homozygous loss of BRCA1 or BRCA2 might cause failure of DNA damage repair, the accumulation of mutations and therefore developing malignancy. BRCA2 is involved in keeping genome stability specifically preserve the flow of homologous recombination to repair double-strand DNA. BRCA2 protein interacts with RAD52 recombinase to configure homologous recombination and mediating the DNA repair mechanism. BRCA2 also plays a role in cell cycle check point. BRCA2 protein regulates the formation of mitotic spindle check point through formation of the spindle protein check point including Aurora A and Aurora B. Our study found that BRCA2 methylation occurred in majority of subjects (98.6\%), but the expression of BRCA2 was still found in $49.3 \%$ of patients. It is suggested to study the molecular functions of BRCA2 in the DNA repair mechanism, to make sure that the expressed BRCA2 was functional. The risk of ovarian cancer for woman with BRCA2 mutation or loss of function is $12-20 \%$, lifetime risk of ovarian cancer might as high as $20-30 \%$ for the BRCA2 gene mutations or loss of function carrier (Chan et al, 2002), Laird, 2003).

\section{BRCA2 expression induced better survival}

Several clinical factors such as age, menarche, parity, menopausal age, nutritional status (BMI), CA125 level before surgery, residual tumor during surgery, histopathological type and grade of differentiation were recorded and analyzed. These clinical parameters of the patients were classified in two or three groups. The results found that the distribution of clinical parameters were not different to the methylation status and expression of BRCA2, and there were no correlation among methylation status and expression of BRCA2 with those clinical parameters ( $p>0.05$ ) (Table 2). Those clinical parameters did not influence the methylation status and expression of BRCA2. However, the occurrence of methylation

Table 3. Bivariable and Multivariable Survival Analysis with Cox's Regression of Clinicopathological Factors, Methylation Status and Protein Expression of BRCA2

\begin{tabular}{|c|c|c|c|c|c|}
\hline \multirow[t]{2}{*}{ Variable } & & \multicolumn{2}{|c|}{ Bivariate analysis } & \multicolumn{2}{|c|}{ Multivariate analysis } \\
\hline & & $\mathrm{HR}(95 \% \mathrm{CI})$ & $\mathrm{p}$ value & $\mathrm{HR}(95 \% \mathrm{CI})$ & $\mathrm{p}$ value \\
\hline Age & $\begin{array}{l}<40 \text { years } \\
>=40 \text { years }\end{array}$ & $\begin{array}{c}\text { Ref. } \\
1.54(0.52-4.59)\end{array}$ & 0.43 & $\begin{array}{c}\text { Ref. } \\
1.35(0.33-5.56)\end{array}$ & 0.67 \\
\hline Age of menarche & $\begin{array}{l}<15 \text { year old } \\
>=15 \text { year old }\end{array}$ & $\begin{array}{c}\text { Ref. } \\
2.55(1.07-6.03)\end{array}$ & 0.03 & $\begin{array}{c}\text { Ref. } \\
2.54(0.92-6.99)\end{array}$ & 0.07 \\
\hline Parity & $\begin{array}{l}<2 \\
>=2\end{array}$ & $\begin{array}{c}\text { Ref. } \\
2.00(0.80-4.96)\end{array}$ & 0.13 & $\begin{array}{c}\text { Ref. } \\
1.84(0.50-6.75)\end{array}$ & 0.35 \\
\hline Menopause & $\begin{array}{l}\text { Non menopause } \\
\text { Menopause }\end{array}$ & $\begin{array}{c}\text { Ref. } \\
0.96(0.62-1.48)\end{array}$ & 0.86 & $\begin{array}{c}\text { Ref. } \\
0.74(0.26-2.14)\end{array}$ & 0.58 \\
\hline BMI & $\begin{array}{l}<25 \mathrm{~kg} \cdot \mathrm{m} 2 \\
>=25 \mathrm{~kg} / \mathrm{m} 2\end{array}$ & $\begin{array}{c}\text { Ref. } \\
0.67(0.22-2.01)\end{array}$ & 0.48 & $\begin{array}{c}\text { Ref. } \\
0.42(0.12-1.46)\end{array}$ & 0.17 \\
\hline CA 125 level & $\begin{array}{l}<=70 \mathrm{IU} / \mathrm{ml} \\
>70 \mathrm{IU} / \mathrm{ml}\end{array}$ & $\begin{array}{c}\text { Ref. } \\
4.11(1.20-14.04)\end{array}$ & 0.02 & $\begin{array}{c}\text { Ref. } \\
2.81(0.61-12.81)\end{array}$ & 0.18 \\
\hline Clinical stage & $\begin{array}{l}\text { Early stage } \\
\text { Late stage }\end{array}$ & $\begin{array}{c}\text { Ref. } \\
0.51(0.27-0.94)\end{array}$ & 0.03 & $\begin{array}{c}\text { Ref. } \\
7.44(1.16-47.37)\end{array}$ & 0.03 \\
\hline Histological type & $\begin{array}{l}\text { Serous } \\
\text { Mucinous } \\
\text { Others }\end{array}$ & $\begin{array}{c}\text { Ref. } \\
0.94(0.48-1.86) \\
0.93(0.52-1.65)\end{array}$ & 0.92 & $\begin{array}{c}\text { Ref. } \\
2.61(0.48-13.98) \\
1.07(0.28-4.08)\end{array}$ & 0.50 \\
\hline Grade of differentiation & $\begin{array}{l}\text { Well } \\
\text { Moderate } \\
\text { Poor }\end{array}$ & $\begin{array}{c}\text { Ref. } \\
0.60(0.32-1.86) \\
0.19(0.63-2.26)\end{array}$ & 0.24 & $\begin{array}{c}\text { Ref. } \\
0.99(0.19-5.15) \\
2.00(0.34-11.53)\end{array}$ & 0.63 \\
\hline Residual tumor & $\begin{array}{l}\text { Optimal surgery } \\
\text { Not optimal }\end{array}$ & $\begin{array}{l}\text { Ref. } \\
0.63(0.41-0.98)\end{array}$ & 0.04 & $\begin{array}{c}\text { Ref. } \\
0.52(0.12-2.10)\end{array}$ & 0.36 \\
\hline Methylation status & $\begin{array}{l}\text { Methylated } \\
\text { Unmethylated }\end{array}$ & $\begin{array}{c}\text { Ref. } \\
4.53(0.00-1047449.83)\end{array}$ & 0.81 & $\begin{array}{l}\text { Ref. } \\
0.00(0.00)\end{array}$ & 0.98 \\
\hline IHC BRCA2 Protein & $\begin{array}{l}\text { Aberrant } \\
\text { Positive }\end{array}$ & $\begin{array}{c}\text { Ref. } \\
1.24(0.77-1.92)\end{array}$ & 0.33 & $\begin{array}{c}\text { Ref. } \\
0.32(0.10-1.01)\end{array}$ & 0.05 \\
\hline
\end{tabular}


was influenced by environtment and nutritional factors as already stated in the literature. Our finding was new evidence for Indonesian people that BRCA genes are highly methylated in ovarian cancer patients, as the previous studied of methylation status for BRCA1 (Pradjatmo et al, 2014). Kontorovich et al (2009) found that BRCA2 does not exhibit a similar methylation profile in ovarian cancer. Findings of previous studies have shown that methylated $\mathrm{CpGs}$ at the BRCA2 promoter were either absent or at very low levels in tumor DNA compared to normal tissues (Chan et al, 2002). Several studies found methylation status of BRCA2 in epithelial ovarian cancer were $11.66 \%$ or 7 of 60 patients (Darehdori et al, 2012; Shabanizadeh et al, 2013), in granulosa cell tumor found BRCA2 methylation $4 \%$ or 1 of 25 patients (Dhillon et al, 2004). Hypermethylation of BRCA2 gene in the epithelial ovarian cancer had large variations in many countries because of differences in environmental factors, chemical exposures, polution factors and nutrition as these greatly affected the occurrence of promoter methylation of suppressor genes and other genes. Aberrant DNA methylation currently is recognized as a common molecular abnormality in cancer and it becomes potential molecular marker for diagnosis, prognosis and treatment (Laird, 2003). This finding has been reported and discussed in the previous studied for BRCA1 there were no correlation among BRCA1 methylation and BRCA1 expression with several clinocopathological factors such as; age, menarche, parity, menopauze status, BMI, CA125 level, clinical stage of disease, histopathological type, grade and residual tumor during surgery (Pradjatmo et al, 2014). Aberrant DNA methylation currently is recognized as a common molecular abnormality in cancer and it may be seen as potential molecular marker for diagnosis, prognosis and treatment (Laird, 2003).

In the Log rank's analysis for bivariable found that methylation status and expression of BRCA2 protein did not influence the survival of the EOC patients with $\mathrm{p}$ $=0.81$ and $\mathrm{p}=0.33$ and some clinical factors those are menarche, CA125 level, stage of disease and residual tumor during surgery independently were significant influence the survival of the EOC patients with HR 2.55 $(\mathrm{p}=0.03), 4.11(\mathrm{p}=0.02), 0.51 \quad(\mathrm{p}=0.01), 0.63(\mathrm{p}=0.04)$ respectively. However, Cox's regression analysis for multivariable analysis only clinical stage and BRCA2 expression influenced the survival of the patients with HR $7.44(\mathrm{p}=0.03)$ and HR $0.32(\mathrm{p}=0.05)$ respectively. When patients are in the late stage the risk of mortality 7.44 times than in early stage, and if the tumor cells express BRCA2 protein the patients are three times more likely to survive than if they did not express BRCA2 (Table 3).

One common DNA modification is promoter hypermethylation associated with loss of expression of tumor suppressor genes. During cancer development, there is a shift in methylation patterns and some $\mathrm{CpG}$ islands in promoter region become methylated leading to silencing of the adjacent genes and this process is considered to be a critical step in cancer development. We found that BRCA2 methylation was found in majority of epithelial ovarian cancer cases $(98.7 \%)$. However, the methylation status was not associated with protein level expression of BRCA2 (49.3\%). Therefore in addition to DNA methylation, other epigenetic mechanisms may regulate the BRCA2 expresison. Our findings may become evidence of BRCA2 inactivation mechanism through DNA methylation in the Indonesian population. More importantly, from the multivariable analysis, BRCA2 expression was correlated with better overall survival (HR $0.32 ; \mathrm{p}=0.05$ ). High percentage of BRCA2 methylation status and correlation of BRCA2 expression with overall survival in ovarian cancer may lead to the development of treatment modality specifically to target methylation of the BRCA gene.

\section{Acknowledgements}

This study was undertaken as part of my thesis of $\mathrm{PhD}$ program. I would like to thank our supervisor; Professor dr. Djaswadi Dasuki SpOG(K), MPH, PhD. Professor dr. Sofia Mubarika PhD. Professor dr. Moh Anwar SpOG(K), MMedSc.

\section{References}

An J, Wei Q, Liu Z et al (2010). Messenger RNA expression and methylation of candidate tumor-suppressor genes and risk of ovarian cancer-a case-control analysis. Inter J of Mol Epid and Gen, 1, 1-10.

Baldwin RL, Nemeth E, Tran H, et al (2000). BRCA1 promoter region hypermethylation in ovarian carcinoma: a populationbased study. Cancer Res, 60, 5329-33.

Bosviel R, Michard E, Lavediaux G, et al (2011). Peripheral blood DNA methylation detected in the BRCA1 or BRCA2 promoter for sporadic ovarian cancer patients and controls. Clinica Chimica acta. Inter J of Clin Chem, 412, 1472-5.

Catteau A, Harris WH, Xu CF, Solomon E (1999). Methylation of the BRCA1 promoter region in sporadic breast and ovarian cancer: correlation with disease characteristics. Oncogene, 18, 1957-65.

Chan KY, Ozcelik H, Cheung AN, Ngan HY, Khoo US (2002). Epigenetic factors controlling the BRCA1 and BRCA2 genes in sporadic ovarian cancer. Cancer Res, 62, 4151- 56.

Darehdori AS, Dastjerdi MN, Dahim H, et al (2012). Lack of significance of the BRCA2 promoter methylation status in Different Genotypes of the MTHFR a1298c polymorphism in ovarian cancer cases in Iran. Asian Pac J Cancer Prev, 13, 1833-6.

Dhillon VS, Shahid M, Husain SA (2004). CpG methylation of the FHIT, FANCF, cyclin-D2, BRCA2 and RUNX3 genes in Granulosa cell tumors (GCTs) of ovarian origin. $\mathrm{Mol}$ Cancer, 3, 1-8.

Gudmundsdottir K, Ashworth A (2006). The roles of BRCA1 and BRCA2 and associated proteins in the maintenance of genomic stability. Oncogene, 25, 5864-74.

Hedenfalk I, Duggan D, Chen Y, et al (2001). Gene-expression profiles in hereditary breast cancer. The New Eng J of Med, 344, 539-48.

Herman JG, Baylin SB, (2003). Gene silencing in cancer in association with promoter hypermethylation. The New Engl $J$ of Medicine, 349, 2042-54.

Hilton JL, Geisler JP, Rathe JA, et al (2002). Inactivation of BRCA1 and BRCA2 in Ovarian Cancer. $J$ Natl Cancer Inst, 94, 1396-406.

Holschneider CH, Berek JS (2000). Ovarian cancer: epidemiology, biology, and prognostic factors. Seminars in Surgical Oncology, 19, 3-10. 
Jones PA (1996). DNA methylation errors and cancer. Cancer Res, 56, 2463-7.

Kontorovich T, Cohen Y, Nir U, Friedman E (2009). Promoter methylation patterns of ATM, ATR, BRCA1, BRCA2 and p53 as putative cancer risk modifiers in Jewish BRCA1/ BRCA2 mutation carriers. Breast Cancer Res Treat, 116, 195-200.

Korstanje R, Albers JJ, Wolfbauer G, et al (2004). Quantitative trait locus mapping of genes that regulate phospholipid transfer activity in SM/J and NZB/BINJ inbred mice. Arteriosclerosis, Thrombosis, and Vascular Biology, 24, 155-60.

Laird PW (2003). The power and the promise of DNA methylation markers. Nat Rev Cancer, 3, 253-66.

Lesnock JL, Darcy KM, Tian C, et al (2013). BRCA1 expression and improved survival in ovarian cancer patients treated with intraperitoneal cisplatin and paclitaxel: a Gynecologic Oncology Group Study. British J Cancer, 108, 1231-7.

Li SD, Zhang JR, Wang YQ,Wan XP 2010. The role of microRNAs in ovarian cancer initiation and progression. $J$ Cell Mol Med, 14, 2240-49.

McCabe N, Turner NC, Lord CJ, et al (2006). Deficiency in the repair of DNA damage by homologous recombination and sensitivity to poly(ADP-ribose) polymerase inhibition. Cancer Res, 66, 8109-15.

Meetei AR, Levitus M, Xue Y, et al (2004). X-linked inheritance of Fanconi anemia complementation group B. Nature Genetics, 36, 1219-24.

Olek A, Oswald J, Walter J (1996). A modified and improved method for bisulphite based cytosine methylation analysis. Nucleic Acids Res, 24, 5064-6.

Pradjatmo H, Dasuki D, Anwar M, Mubarika S, Harijadi (2014). Methylation status and immunohistochemistry of BRCA1 in epithelial ovarian cancer. Asian Pac J Cancer Prev, 15, 9479-85.

Rathi A, Virmani AK, Schorge JO, et al (2002). Methylation profiles of sporadic ovarian tumors and nonmalignant ovaries from high-risk women. Clin Cancer Res, 8, 3324-31.

Shabanizadeh A, Dahim H, Salahshoor R, et al (2013). Promoter methylation status and protein expression of BRCA2 in patients with epithelial ovarian cancer. Middle East Journal of Cancer , 4, 15-20.

Thrall M, Gallion HH, Kryscio R, et al (2006). BRCA1 expression in a large series of sporadic ovarian carcinomas: a Gynecologic Oncology Group study. Inter J of Gynecol Cancer, 16, 166-71.

Venkitaraman AR (2002). Cancer susceptibility and the functions of BRCA1 and BRCA2. Cell, 108, 171-82.

Yanagawa N, Tamura G, Honda T, et al (2004). Demethylation of the synuclein gamma gene $\mathrm{CpG}$ island in primary gastric cancers and gastric cancer cell lines. Clin Cancer Res, 10, 2447-51. 